Copyright @ 2001 SAGE Publications (London, Thousand Oaks, CA and New Delhi) Vol 1(1):109-140 [1468-7968(200104)1:1;109-140;016695]

\title{
Bhikhu Parekh
}

Rethinking Multiculturalism: Cultural Diversity and Political Theory London: Macmillan, 2000. xii + 367 pp. ISBN 0-3336-0881-X (hbk), ISBN 0-3336-0882-8 (pbk)

\section{Cherishing diversity and promoting political community}

\section{RAINER BAUBÖCK}

Austrian Academy of Sciences, Vienna

B hikhu Parekh's voice has always been a distinctive one in the growing chorus of political theorists who talk about the challenge of cultural diversity. $\mathrm{H}$ is perspective is not easy to classify. $\mathrm{He}$ criticizes liberal, communitarian or neorepublican theories and yet combines their core ideas in his own approach. Some readers of R ethinking Multiculturalism may feel that his outlook is too ecumenical. Parekh defends not only cultural, but also doctrinal diversity and this can occasionally be frustrating for critics who expect a political theory to provide a straightforward path from first principles to the resolution of hard cases. Y et Parekh's book is not at all eclectic. There is an underlying concern that organizes the text and gives it a distinctive edge. In my reading this is the idea that cultural diversity is an intrinsic value.

M ost liberal theories see cultural diversity as a fact rather than a value. D epending on their ranking of other values they arrive at quite different perspectives on how public policies should deal with diversity. While some argue for nearly unlimited toleration within a thin public sphere that emerges only from a spontaneous consensus between cultural communities (K ukathas, 1997), others defend an egalitarian conception of citizenship that permits for cultural exemptions in a limited number of cases (B arry, 2000). For Kymlicka (1995) the value of membership in a cultural community is 
derived from, and constrained by, what it contributes to the liberal value of individual autonomy, whereas R awls (1993) searches for a purely political conception of justice that can be endorsed by liberal as well as non-liberal doctrines. L evy (2000) defends a 'multiculturalism of fear' that is primarily worried about the negative potential of humiliation and oppression in contexts of cultural diversity, while Taylor (1992) focuses on the positive values of dignity and authenticity that drive the politics of cultural recognition. Parekh's approach differs not only from liberals whom he accuses of continuing a long tradition of moral monism, but also from communitarians, pluralists and moderate nationalists who value the integrity of distinct traditions but want to limit diversity when it undermines homogeneity within communities and cuts across their boundaries.

Parekh's conception of diversity, however, is not a postmodern celebration of hybridity or cultural globalization either. While self-enclosed cultures can be 'repressive, intolerant, narrow, inward-looking and authoritarian', culturally open ways of life risk becoming 'shallow, eclectic, bland, thin and devoid of coherence and historical depth' ( $p .172$ ). D iversity is thus only valuable if it is jointly generated by communities whose members are not culturally footloose (p. 150) but cherish their own traditions. Parekh also dismisses instrumental defences of cultural diversity on aesthetic grounds or because it promotes competition and development. Instead, he emphasizes its moral and political value. For individuals, diversity is a 'constituent and condition of human freedom' (p. 167); it enables them to view their own culture from the outside. For the wider society, recognizing the value of diversity is the precondition for an ongoing crosscultural dialogue that mediates conflicting claims of communities.

I find Parekh's basic argument on these points convincing. Y et I have some reservations about how he applies it within the political sphere. D emocratic citizenship and public policies must respond to cultural diversity in society, but laws and policies have to be justified through reasons that all citizens can share as members of a political community. The demands of cultural communities must therefore be translated into the language of citizenship. Most liberal and republican theorists have drawn too sharp a line between, on the one side, a supposedly neutral and homogenous political sphere and, on the other side, civil society as the realm of diversity. Parekh, however, sometimes blurs this boundary to such an extent that the two spheres and their distinct modes of integration are no longer recognizable. I will pick out two propositions that nourish this doubt: first, Parekh's claim that individuals have an obligation to be loyal to their cultures and, second, his suggestion that specific political arrangements for cultural communities can be grounded in the value of diversity. 


\section{CULTURAL LOYALTY}

B ecause sustainable diversity needs culturally rooted individuals, Parekh proposes that individuals have obligations of loyalty towards the culture in which they have grown up and towards the community that is associated with this culture. We have duties of gratitude for what this culture has contributed to our lives; duties towards mankind and future generations to preserve and pass on what is of universal value in this culture; duties to defend our cultural community when it is unjustly attacked from outside, but also a special duty to criticize its internal injustices and repression (pp. 160-2).

From the perspective of a cultural community it is perfectly natural to expect its members to be loyal for all these reasons. A nd because individuals grow up in cultural communities, they normally develop a sense of belonging that creates a disposition to be loyal. This disposition is generally stronger than it is in voluntary associations whom we join in order to pursue some specific interest. A II this explains why cultural loyalty is widespread and also why it would be wrong to expect individuals to renounce it in their ethical choices. Yet I remain puzzled by the idea that we would also have moral or political obligations of cultural loyalty. Isn't the point of calling an obligation a moral one that we regard it as binding even those who are not disposed to comply with it?

Parekh himself is very clear that a legal obligation of cultural loyalty would be illegitimate: 'A culture has no authority other than that derived from the willing allegiance of its members ... no culture can therefore be preserved by force or artificial means' ( $p .169)$. He even says that ' $(t)$ here is nothing wrong with assimilation. If minorities freely decide to assimilate into the dominant culture, their decisions should be respected and they should be given every opportunity to do so' ( p. 197). H ow can this be reconciled with a demand for cultural loyalty? Parekh could claim that external pressure on a community to either preserve or abandon its culture in a wholesale way is morally wrong but that it is also wrong for members of such communities to disavow their cultural affiliations unless they have strong reasons to do so.

Let me consider the second part of this proposition in the critical contexts of emigration and external attack. D o people who leave their home country to earn a higher income elsewhere violate a duty towards their cultural community because they will no longer contribute to its flourishing? A fter establishing themselves in their new country of residence do they still have an ongoing duty towards their culture of origin, for example to teach their children their own native language? I think that if there is no pressure on them to leave and no pressure to assimilate after immigration their decisions to do so should be seen as morally unconstrained even if they feel bad about them and are severely criticized within their community. But 
what if there is such pressure or if the community is unjustly attacked? R esistance against coercive assimilation is admirable and external aggression against a cultural community will normally trigger an awareness of belonging even among those who had previously dissociated themselves. ${ }^{1}$ $Y$ et even in this case I wonder whether resistance and defence are a special moral obligation towards one's own community. It is wrong to blame the victims of coercive assimilation for not resisting at all costs. If there is a truly moral duty to denounce and resist attacks on a minority, it is the duty of citizens who belong to the majority in whose name this aggression is committed.

My conclusion is that we should distinguish more sharply than Parekh does between the particular ethos of cultural communities and the moral or political duties that are grounded in the human condition or in citizenship of a democratic polity. The ethos of cultural communities will naturally include duties of loyalty. We may want such communities to be able to sustain that ethos and retain the voluntary allegiance of their members. $\mathrm{H}$ owever, if membership is voluntary, exit must be an option that is not only possible but is also accepted as a morally legitimate choice. While citizens have a strong duty towards each other to respect their cultural affiliations and to prevent unjust attacks on any cultural community, they are - as citizens - not bound to remain loyal to their own communities even if this is what their community rightly expects from them as long as they are members.

\section{THE VALUE OF DIVERSITY}

Turning to my second question let me consider what is implied in calling cultural diversity an intrinsic value. Diversity is, first, an important fact in all periods of human history that results from the dual nature of human beings as social and as self-interpreting animals. Diversity assumes, secondly, special features within modern societies, which are characterized by dialectics of cultural homogenization through nation-building and of increasing heterogeneity through crosscultural mobility and political mobilization of minorities. Y et many societies have experienced and still experience cultural diversity as a predicament rather than an asset. A s R awls (1999: 11-12) puts it, the task of normative political theory is to develop realistic utopias that reconcile us with the facts of pluralism and diversity by showing how these conditions contribute to justice and liberty. This implies attributing value, but not necessarily intrinsic value, to cultural diversity.

We can regard the value of diversity as either derivative of, or instrumental for the achievement of other values that are good in themselves. Lord Dalberg-A cton's (1907) defence of national diversity within democratic 
polities combines both these arguments: 'Liberty provokes diversity, and diversity preserves liberty by supplying the means of organisation' (p. 289). The value of diversity is, first, derivative, because it results from the exercise of activities of speech, assembly and association that are universal human rights and protected as basic liberties in all modern democratic constitutions. It is not the particular content of the protected activities which partakes in this way in the intrinsic value of liberty - there is no need to attribute any value to the opinions of religious bigots or racists - but if we value liberty we must necessarily also value the irreducible diversity of cultural perspectives and ways of life. A desire for cultural homogeneity is incompatible with a proper understanding of what liberty entails. Secondly, the value of diversity is instrumental because, as D alberg-A cton argues, cultural and national diversity reduces the concentration of political power within a state. Multinational diversity leads to federal arrangements of power sharing between constituent units and multicultural diversity finds its organized expression in civil society associations that lobby and control public institutions.

O ne can probably provide similar arguments for diversity that derive from, or are instrumental for, values other than liberty. The question is then what is added by calling diversity an intrinsic value. Parekh suggests several interconnected reasons: (1) 'no culture embodies all that is valuable in human life and develops the full range of human possibilities' (p. 167); (2) cultural diversity provides human beings with 'mini-A rchimedian standpoints that enable them to view their own [culture] from the outside, tease out its strengths and weaknesses, and deepen their self-consciousness' (p. 167); (3) 'The diversity of cultures also alerts us to that within our own' (p. 168); and (4) it 'creates a climate in which different cultures can engage in a mutually beneficial dialogue' (p. 168).

I agree with all this and want to highlight the political implications of the last point. A 'multiculturalism of fear' (Levy, 2000) is similar to a $\mathrm{H}$ obbesian conception of political power as an external force needed to overawe the anarchical interests and passions in society. It may support a far-ranging accommodation of cultural claims for the sake of securing peaceful relations between groups, political stability of states, and standards of decency in social interaction. However, it cannot mobilize a common sense of belonging and participation in the polity grounded in a mutual appreciation of what each culture contributes. By contrast, Parekh's theory of diversity is more like a R ousseauian conception that regards citizens as capable of governing themselves and of developing a commitment to a common good. It should be easier to reconcile the occasionally conflicting claims of democratic citizenship and of cultural community if both cultural diversity and self-government are seen as good in themselves and as essential aspects of human freedom and well-being. However, in order to reconcile them, we first have to recognize their different logics. We should not use 
political criteria for the evaluation of cultures and we should not base political decisions on reasons that are only available from within a certain cultural perspective.

Parekh criticizes, for example, the 'pervasive tendency among religious people to claim to be in possession of divinely vouchsafed infallible truths'. B ecause every religion is at least partly a human construction, he regards this as 'a wholly false reading of religion' (p. 334). W ith such arguments Parekh hopes to show that religious communities ought to accept the diversity of faiths and the constraints of democratic society. This does not capture the profound tension between a sincere belief in divinely revealed truth and the demands of citizenship. Parekh attempts to derive a politically desirable result from a certain interpretation of religion. ${ }^{2}$ Promoting interreligious dialogue may help to prevent religious conflicts from escalating into violence. B ut, as the document 'D ominus J esus', which was recently issued by the Vatican, shows, decades of peaceful dialogue may not shatter the belief of religious authorities that they are in the exclusive possession of revealed truth and that humanity would be better off if it were united in a single church.

From the perspective of a democratic polity the value of religious diversity is, on the one hand, that it creates a context in which even those who hold such beliefs are likely to acquire a second, non-religious identity as citizens and learn to respect and endorse arrangements that do not privilege their faith. On the other hand, the value of a diversity of ways of life can justify special exemptions from general obligations of citizenship for groups like the A mish or certain monastic orders whose religious identity forces them to withdraw from the public life of the wider society. What political authorities cannot and must not do is to engage in interpreting religious doctrines in a way that makes them more conducive for democratic citizenship. This does not mean that religious arguments should be banned in all deliberations about public policies. ${ }^{3}$ It does, however, imply that no political decision is legitimate that can only be justified in terms of religious reasons.

While cultural diversity may thus play a legitimate role in the justification of special group rights, it is never a sufficient argument. ${ }^{4}$ If one wants to promote diversity for its own sake, any rights claimed by one cultural community should be extended to all other groups of a similar kind. This would undermine the special arrangements for Francophones in Canada and Catalans in Spain, for O rthodox Jews in I srael and M uslims in India that Parekh discusses and defends. It is only from a perspective of democratic citizenship as a project of political integration in a society with a particular composition and history that we can justify what otherwise must appear as arbitrary privileges.

Cherishing diversity and promoting democratic community are then mutually supportive but not identical tasks. Parekh's book helps us to 
understand the complexity of each of these values. F uture theories of multiculturalism can build on these foundations when they try to explain how they relate to each other.

\section{Notes}

1 A s H annah A rendt put it: 'If I am attacked as a J ew, I can only defend myself as a J ew'.

2 This is somewhat similar to Locke's (1956) argument for religious toleration, which proclaims, contrary to evidence, that a church is 'a free and voluntary society. Nobody is born a member of any church' (p. 131).

3 Contrary to what Parekh suggests on p. 89, Rawls's (1999) conception of public reason 'allows us to introduce into political discussion at any time our comprehensive doctrine, religious or nonreligious, provided that, in due course, we give properly public reasons to support the principles and policies our comprehensive doctrine is said to support' (p. 144).

4 See also B auböck (1999: 147-53).

\section{References}

Barry, B rian (2000) Culture and E quality: A n E galitarian Critique of M ulticulturalism. L ondon: Polity.

B auböck, R ainer ( 1999) 'L iberal J ustifications for E thnic G roup R ights', in Christian J oppke and Steven Lukes (eds) M ulticultural Q uestions. O xford: O xford U niversity Press.

D alberg-A cton, J ohn E.E. (1907) 'N ationality', in J ohn E.E . D alberg-A cton (ed.) The $\mathrm{H}$ istory of F reedom and other $\mathrm{E}$ ssays. L ondon: M acmillan.

Kukathas, Chandran (1997) 'Cultural Toleration', in W ill Kymlicka and I an Shapiro (eds) Ethnicity and G roup Rights, Nomos XXXIX, Y earbook of the A merican Society for Political and Legal Philosophy. New York: New York U niversity Press.

Kymlicka, Will (1995) Multicultural Citizenship: A Liberal Theory of Minority Rights. Oxford: Clarendon Press.

Levy, Jacob T. (2000) The Multiculturalism of Fear. Oxford: Oxford U niversity Press.

Locke, John (1956) 'A Letter Concerning Toleration', in The Second Treatise of Government and A L etter Concerning Toleration. N ew Y ork: M acmillan.

R awls, J ohn (1993) Political L iberalism. N ew York: Columbia U niversity Press.

R awls, J ohn (1999) The L aw of Peoples; with the Idea of Public Reason Revisited. Cambridge, M A : H arvard U niversity Press.

Taylor, Charles (1992) 'The Politics of R ecognition', in A my G utmann (ed.) M ulticulturalism and the Politics of Recognition. Princeton, $\mathrm{NJ}$ : Princeton U niversity Press. 


\section{Thoughts on multicultural dialogue}

\section{IRIS MARION YOUNG}

University of Chicago

The project of Rethinking Multiculturalism consists less of an effort to develop a political theory of multiculturalism from the ground up than a contribution to a conversation which has been going on for some time, even centuries, to reflect on and evaluate positions that have been taken so far. Parekh offers much that is fresh and original both in his critical review of political philosophers on cultural pluralism, and in his account of culture, human value, and the meaning of justice and equality in a multicultural society. $\mathrm{He}$ is less disposed than many philosophers, however, to clear the table of inadequate positions in order to replace them with his own. Instead, he sifts through the previous discussion to find what wisdom there is, and builds on it. In this respect as well as others, Parekh's style and tone exemplifies the dialogic attitude whose importance he also theorizes substantively in the book.

It would be tedious to try to summarize all the important points Parekh makes, and the breadth of issues he treats makes the task too difficult in any case. In the short space I have I will focus on how Parekh understands the subject of a political theory of multiculturalism and the recommendations about dialogue that he makes for it. To some of his interesting and provocative ideas I will add some of my own.

\section{CULTURAL PLURALISM VS MULTICULTURALISM}

Parekh distinguishes between the facts of a multicultural society, and a particular normative attitude to take toward those facts, which is multiculturalism proper. N early all societies in the world today and many of the past are multicultural, that is, composed of several cultural groups who understand themselves as distinct in certain respects but nevertheless interacting within the society. M ulticulturalism consists of the assertion of normative principles that affirm the value of such cultural diversity in terms of equality between groups, and the realization of these values in institutions and policies. D espite the factual presence of cultural differences within them, few polities are adequately multicultural in this normative sense, and many explicitly reject such multicultural values. Parekh thinks that all multicultural societies, however, ought to embrace multicultural values and policies.

Important chapters of R ethinking M ulticulturalism evaluate contemporary liberal approaches to cultural pluralism, particularly in the work of 